\title{
Inclusive Road Infrastructure Safety Management in the Settlement - an Approach to Improving the Safety of Vulnerable Road Users
}

\author{
MILENKO R. ČABARKAPA, Adriatic University Bar, \\ Faculty of Traffic, Communications \\ and Logistics, Budva, Montenegro
}

Previous announcement

$U D C: 656.1 .08$

656.1 .053

DOI: 10.5937/tehnika2006777C

\begin{abstract}
In the last ten years, there has been a stabilization of traffic fatalities on the roads of the world. At the same time, the death toll of persons in the armor of vehicles was reduced, and the death toll of persons outside the armor of vehicles-vulnerable road users continued to grow. The most endangered are motorcyclists, then pedestrians and finally cyclists, both in developed countries of the European Union and in underdeveloped and developing countries. Lagging behind in reducing the fatalities of vulnerable road users requires innovation in research and the creation and implementation of new road safety management policies. In this aspect, inclusive road infrastructure safety management in the settlement can be a paradigm for the introduction and implementation of protection of vulnerable road users, persons with reduced mobility and persons with disabilities, through procedures to control road safety in the settlement, at all stages of the road life cycle: planning, design, construction and exploitation. The content of inclusive road infrastructure safety management in the settlement should include all areas of activity and all elements of the roads of the settlement, the improvement of which can raise the level of traffic safety of all users, so that the roads of the settlement are equally safe for all road users. At the same time, the risk of fatal traffic accidents on the roads of the settlement is indirectly exponentially related to the scope of the content of inclusive road infrastructure safety management in the settlement.
\end{abstract}

Key words: inclusive management, road infrastructure safety in the settlement, protection, vulnerable road users

\section{INTRODUCTION}

The road traffic system, which is based primarily on development, and protection was of secondary importance, generated that injuries in road traffic have become a global problem [1].

In the period 2007-2010-2013-2016, the annual number of road traffic fatalities of the world was 1.3 1.24-1.25-1.35 million people [2].

Injuries in road traffic were the tenth leading cause of death in the world in 2007, in the period 2010-2013 they were the ninth leading cause of death in the world, and in 2016 they reached the level of the eighth leading cause of death in the world [2]. At the same time, in the period 2007-2016, road traffic injuries were the first leading cause of death in the world among young

Author's address: Milenko Čabarkapa, Faculty of Traffic, Communications and Logistics Budva, Žrtava fašizma 56, Montenegro

e-mail: milenko.cabarkapa.me@gmail.com

Paper received: 16.10.2020.

Paper accepted: 09.11.2020. people aged 15-29.

In $2016,93 \%$ of the world's road fatalities occur in underdeveloped and middle-developed countries, which own $60 \%$ of the world's registered vehicles, and in developed countries, which own $40 \%$ of registered vehicles occur $7 \%$ of the world's road traffic fatalities [2].

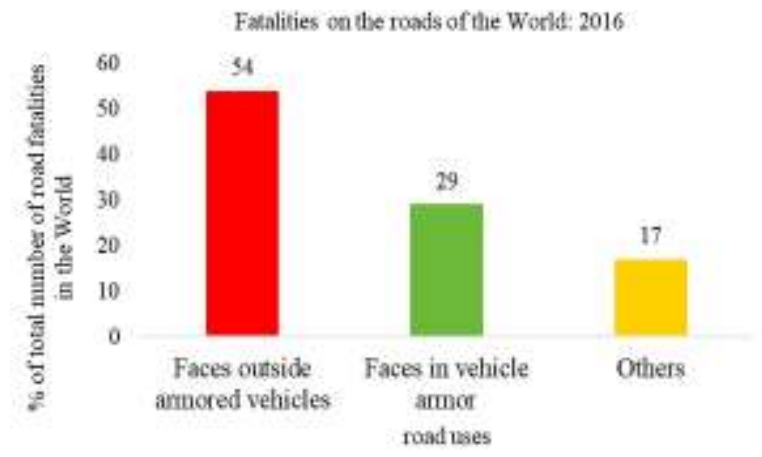

Figure 1-Fatalities on the roads of the world: 2016

In the total number of road traffic fatalities in the world in 2016, the largest share is of road users outside the armor of vehicles: motorcyclists, pedestrians and 
cyclists (Vulnerable Road Users) was 54\%, while participants in the armor of vehicles were $29 \%$ and other participants 17\% [2], (Figure 1).

Given that the mobility of Vulnerable Road Users is more pronounced in settlements and that road infrastructure safety management is mainly established and implemented for roads outside settlements, there is a need for inclusive road infrastructure safety management in settlements, which would, taking into account the need of Vulnerable Road Users, persons with reduced mobility and persons with disabilities, have ensured the improvement of the physical infrastructure of the settlement roads for these most vulnerable road users, so that the settlement roads are equally safe for all road users.

\section{PROBLEM OF SAFETY OF VULNERABLE ROAD USERS}

Vulnerable Road Users are the participants with the highest risk of injury in road traffic and among them pedestrians and cyclists are particularly at risk [3]. It is a group of road users whose chances of receiving injuries are much higher than inflicting them on other road users [4]. In terms of road infrastructure safety management, Vulnerable Road Users are nonmotorized road users: pedestrians and cyclists, including drivers and passengers of motor vehicles on two wheels [5]. However, based on psychological factors that affect road traffic safety, vulnerable road users should include persons with reduced mobility and persons with disabilities.

The share of Vulnerable Road Users: pedestrians, cyclists and motorcyclists in the total number of road traffic fatalities of the world in 2007 was $46 \%$ (WHO, 2009), in 2010 50\% (WHO, 2013), and in $201654 \%$ (WHO, 2018), (Figure 2). In this trend, which is excellently described by a linear function (correlation coefficient is 0.982 , determination coefficient is 0.96 ), the share of Vulnerable Road Users in the total number of road traffic fatalities of the world now, in 2020, would be $58 \%$ (Figure 2).

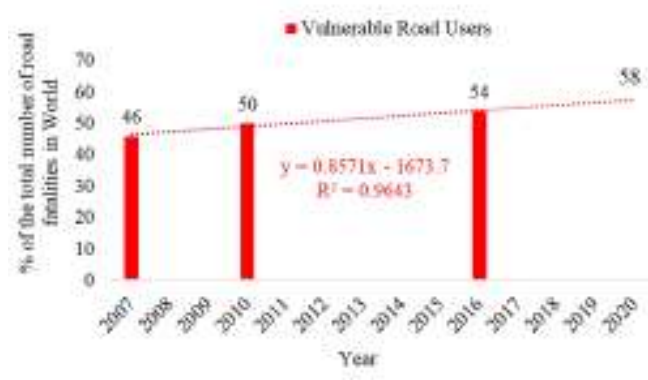

Figure 2 - Share of VRU in fatalities on the roads of the world

In the total number of road traffic fatalities of the world in 2016, the share of motorcyclists was $28 \%$, pedestrians 23\% and cyclists 3\% (WHO, 2018), (Figure 3).

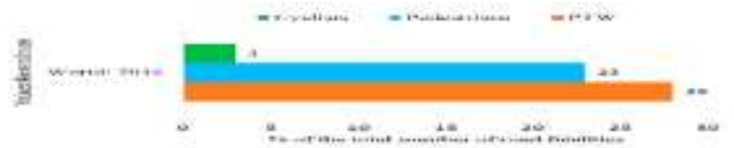

Figure 3 - Share of VRU groups in fatalities, world, 2016

\section{PROBLEM OF ROAD INFRASTRUCTURE SAFETY MANAGEMENT}

Road infrastructure safety management is defined as a set of procedures for road infrastructure safety, which should relate to the entire life cycle of roads: planning, design, commissioning and use. $[6,7,9,10]$. This implies a proactive and reactive approach to road management for improving traffic safety [11]. The following procedures for road infrastructure safety are being established and implemented [5, 6]:

- assessments of the impact of state roads on traffic safety,

- audits of state road safety,

- road safety checks and

- network road safety assessments at the level of the entire network,

which, more recently, include the needs of Vulnerable Road Users [5]. However, these procedures are established and implemented only on state roads outside urban areas, and the mobility of Vulnerable Road Users, especially pedestrians and cyclists, persons with reduced mobility and persons with disabilities, is more pronounced in urban areas, whose traffic network is not subject to listed procedures for road infrastructure safety.

\section{INCLUSIVE ROAD INFRASTRUCTURE SAFETY MANAGEMENT IN THE SETTLEMENT}

Management of the road traffic safety system, in addition to the national one, must also take place at the local level [12]. Although the local road safety system can, in functional terms, be set up analogously to the national system, its framework is much narrower and thus places much more specific and greater demands on local road safety management to adapt the local road infrastructure safety management system in the settlement to local conditions [13].

Inclusive road infrastructure safety management in the settlement should, taking into account the needs of Vulnerable Road Users (non-motorized participants: pedestrians, especially children and cyclists and users of two-wheeled motor vehicles), persons with reduced mobility and persons with disabilities, ensure improvement of physical infrastructure of settlement roads 
for these most vulnerable road users, so that the roads of the settlement are equally safe for all participants.

Safe roads in the settlement should raise the general level of safety, including, before all, improvements in terms of technological progress and the quality of the road network of all users, especially the most Vulnerable Road Users, through planning, design, construction and exploitation of ,self-explanatory and self-executing roads“ and ,areas along forgiving roads" $[14,15,16]$.

In this context, starting from general statistics on traffic accidents and based on a detailed analysis of traffic accidents on roads in the settlement, the content of inclusive road infrastructure safety management in the settlement should include the following areas of activity and elements of settlement roads:

- Planning the use of settlement space for safe traffic of all participants,

- Pedestrian content,

- Content for cyclists,

- Density and position of crossings for pedestrians and cyclists,

- Separation of pedestrians and cyclists from highspeed motor traffic,

- Content for two-wheeled motor vehicles,

- Pedestrian zones,

- Slow traffic zones,

- Zone ,30“,

- Location of schools and school zones,

- Safety of children on the way to and from school,

- Vehicle entrances to the building, yard and garage,

- Technical means for slowing down traffic,

- Technical regulation of traffic,

- Protection at public passenger transport stops,

- Protective fences for pedestrians,

- Ensuring traffic safety in the zone of road crossing over the railway,

- Ensuring traffic safety in the construction site zone,

- Ensuring traffic safety in the zone of performing communal works on the road,

- Security aspect of advertisements and advertising in the field of roads,

- Local traffic restrictions,

- Elements of accessibility of public transport for persons with reduced mobility and persons with disabilities: stops and platforms; parking spaces; public pedestrian areas; traffic lights; pedestrian crossings; pedestrian islands and intersections.

\section{DISCUSSION}

The research of pedestrian fatality tendencies in the period 2007-2018 in Montenegro, in general, determines the decreasing trend of pedestrian mortality, which can be described by a good indirect exponential relationship with the time course of the analyzed period (correlation coefficient is 0.721 ; determination coefficient is 0.59 ), (Figure 4). However, this general decrease in pedestrian mortality is characterized by inequality and variability, increasing pedestrian mortality in some years, especially in 2010 and 2013 and slightly in 2016 and 2018, which indicates insufficient development of pedestrian safety system on the roads of Montenegro, because, for now, a more pronounced is normative in relation to the implementation and practical aspect. In this regard, the procedure of traffic regulation in the pedestrian zone, slow traffic zone, zone ,30“, school zone, for unimpeded movement and access to facilities for persons with reduced mobility and persons with disabilities has been standardized [18] and modern procedures for improving road safety have been introduced in accordance with Directive [5] amending Directive [6], with the introduction of legal liability of road designers and contractors for road infrastructure safety [18].

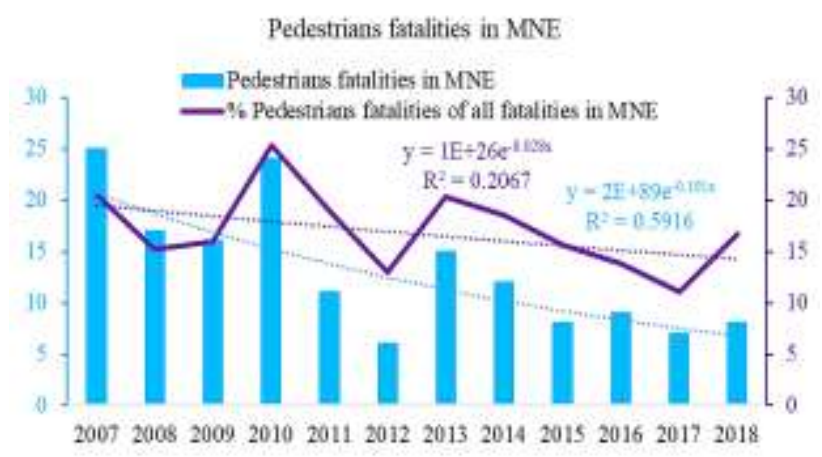

Figure 4 - Tendencies in pedestrians fatality in road traffic, Montenegro, 2007-2018

By researching the distribution of pedestrian and VRU casualties in relation to the category of roads in Montenegro, in 2016, an excellent connection was found between all levels of casualties: fatal, severely injured, lightly injured, in which casualties of pedestrian and VRUs on the streets in urban area are the most numerous, then on the main, then local roads, and the least on regional and uncategorized roads. In this case, the correlation of pedestrian injury is an excellent direct exponential (correlation coefficient is 0.950 ; coefficient of determination is 0.975 ), and the correlation of VRU-s injury is an excellent direct exponential (correlation coefficient is 0.999; coefficient of determination is 0.99), (Figure 5), [10]. 


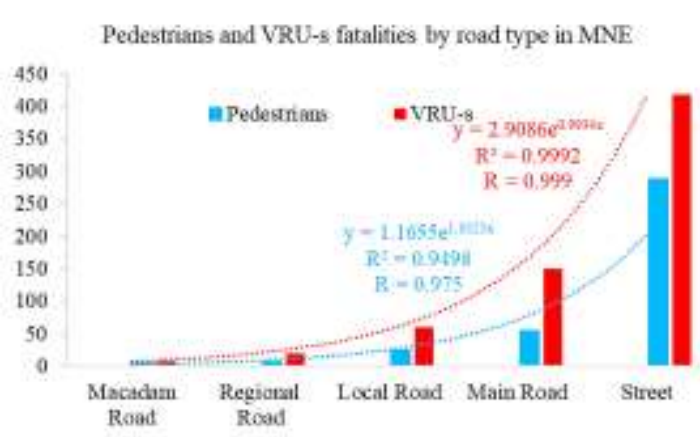

Figure 5 - Distributions of pedestrian and VRU fatalities in relation to the road category, Montenegro, 2016

These findings affirm the introduction of inclusive road infrastructure safety management in the settlement, as an approach to the protection of Vulnerable Road Users, especially pedestrians.

\section{CONCLUSION}

Inclusive road infrastructure safety management in the settlement should, taking into account the needs of Vulnerable Road Users (non-motorized participants: pedestrians, especially children and cyclists and users of two-wheeled motor vehicles), persons with reduced mobility and persons with disabilities, ensure improvement of physical infrastructure of the settlement roads for these most vulnerable road users, so that the roads of the settlement are equally safe for all participants.

The content of inclusive road infrastructure safety management in the settlement should include all areas of activity and all elements of roads of the settlement whose improvement can raise the level of traffic safety of all users, especially the most Vulnerable Road Users, persons with reduced mobility and persons with disabilities, through planning, design, construction and exploitation of roads in the settlement.

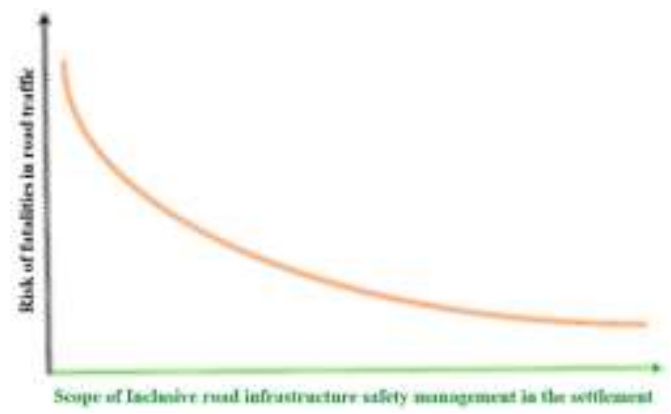

Figure 6-Risk of traffic fatality as a function of the scope of inclusive road infrastructure safety management of the settlement

The risk of traffic fatality on the roads of the settlement is indirectly exponentially related to the scope of inclusive road infrastructure safety management in the settlement (Figure 6).

\section{REFERENCES}

[1] World Health Organisation (WHO). World report on road traffic injury prevention [Internet]. WHO, Geneva, 2004 [quoted 05.07.2006]. Available at: http://whqlibdoc.who.int/publications/2004/924156 2609.pdf

[2] World Health Organisation (WHO). Global status report on road safety [Internet]. WHO, Geneva, 2009, 2013, 2015, 2018 [quoted 20.12.2018]. Available at: http://www.un.org/ar/roadsafety/pdf/roadsafetyreport.pdf

[3] Organization for Economic Cooperation and Development (OECD). Safety of vulnerable road users. [Internet]. OECD, Paris, 1998 [quoted 05.07.2000]. Available at: http://www.oecd.org/sti/transport/roadtransportresearch/2103492.pdf

[4] Walker I, Psychological factors affecting the safety of vulnerable road users: A review of the literature [Internet]. University of Bath, England, 2004 [quoted 09.11.2006]. Available at: http://staff.bath.ac.u/pssiw/traffic/Walkerreview.pdf

[5] European Commission. Directive (EU) 2019/1936 of the European Parliament and of the Council of 23 October 2019 amending Directive 2008/96/EC on road infrastructure safety management [Internet]. EC, Brussels, 2019 [quoted 25.05.2020]. Available at: https://eur-lex.europa.eu/legal-content/EN/TXT/PDF/?uri=CELEX:32019L1936\&from=EN

[6] European Commission. Directive 2008/96/EC of the European parliament and of the council - On road infrastructure safety management [Internet]. EC, Brussels, 2008 [quoted 20.01.2010]. Available at: http://eur-ex.europa. eu/LexUriServ/LexUriServ.do?uri=OJ:L:2008:319:0059:0067:EN:PD

[7] Elvik R, Assessment and applicability of road safety management evaluation tools: Current practice and state-of-the-art in Europe. ТØI (Institute of Transport Economics), Oslo, Norway, 2010.

[8] Schermers G, Cardoso J, Elvik R et al. Guidelines for development and application of Evaluation Tools for road infrastructure safety management in the EU. SWOV, Hague, Netherlands, 2011.

[9] Persia L, Usami D. S, De Simone F. et al. Management of road infrastructure safety. Transportation Research Procedia, Vol. 14, pp. 3436-3445, 2016. doi: 10.1016/j.trpro.2016.05.303,

[10]Čabarkapa, M., Avramović, Ž.Z., \& Vešović, V. The control of road infrastructure safety management procedures. International Journal of Traffic and 
Transportation Engineering, 7(1), 7-14, 2018. doi:10.5923/j.ijtte.20180701.02

[11]International Traffic Safety Data and Analysis Group (IRTAD). Road infrastructure safety management. IRTAD. Paris, 2015.

[12]Čabarkapa M, Road Safety: From Global to Local and Vice Versa. Cambridge Scholars Publishing, Newcastle upon Tyne, UK, 2019. ISBN(10):1-52753833-8, ISBN(13):978-1-5275-3833-7

[13]Čabarkapa M. \& Avramović, Ž. Z, Focus Areas and Measures to Improve Road Traffic Safety at the Local Level. Management, 7(2), 75-83, 2017. doi: 10.5923/j.mm.20170702.01

[14]Theeuwes, J. \& Godthelp, H, Self-explaining roads. Safety Science, 19, 217-225, 1995.
[15]Bekiaris E. \& Gaitanidou E, Towards Forgiving and Self-Explanatory Roads. Infrastructure and Safety in a Collaborative World. Springer, 2011.

[16]Mackiea H. W, Charltonb S. G, Baasc P. H. \& Villasenorc P. C, Road user behaviour changes following a self-explaining roads intervention. Accident Analysis and Prevention, 50, 742-50, 2013. doi: 10.1016/j.aap.2012.06.026.

[17]Čabarkapa M, A problem of the safety of vulnerable road users in Montenegro. International Journal of Injury Control and Safety Promotion, 25(4), 352364, 2018. doi:10.1080/17457300.2018.1431936

[18]Montenegro, Title in Montenegrin [Title in English: Law on Road Traffic Safety, Rulebook on closer conditions and manner of adjustment of facilities for access and movement of persons with reduced mobility and persons with disabilities, Law on Roads [Internet]. Montenegro Gazzete, Podgorica, 2012, 2013, 2014, 2019, 2020 [quoted 10.09.2020]. Available at: http://www.sluzbenilist.me/slpretraga/

\section{REZIME}

\section{INKLUZIVNI MENADŽMENT BEZBJEDNOSTI INFRASTRUKTURE PUTEVA U NASELJU - PRISTUP ZA UNAPREĐENJE BEZBJEDNOSTI RANJIVIH UČESNIKA U SAOBRAĆAJU}

Posljednjih deset godina došlo je do stabilizacije smrtnog stradanja u saobraćaju na putevima svijeta. Pri tome, smanjeno je smrtno stradanje lica u oklopu vozila, a smrtno stradanje lica van oklopa vozilaranjivih učesnika u saobraćaju nastavilo je da raste. Najugroženiji su motocikisti, pa pješaci i na kraju biciklisti, kako u razvijenim zemljama Evropske unije, tako i u nerazvijenim i zemljama u razvoju. Zaostajanje u smanjenju smrtnog stradanja ranjivih učesnika u saobraćaju zahtijeva inovacije $u$ istraživanju i kreiranje i sprovođenje novih politika upravljanja bezbjednošću saobraćaja na putevima. U tom aspektu inkluzivni menadžment bezbjednosti infrastrukture puteva u naselju može biti paradigma za uvođenje i sprovođenje zaštite ranjivih učesnika u saobraćaju, lica smanjene pokretljivosti i lica sa invaliditetom, kroz postupke kontrole bezbjednosti puteva u naselju, u svim fazama životnog ciklusa puta: planiranju, projektovanju, izgradnji i upotrebi. Sadržaj inkluzivnog menadžmenta bezbjednosti infrastrukture puteva u naselju treba da obuhvati sve oblasti djelovanja $i$ sve elemente puteva naselja čijim unapređenjem se može podići nivo bezbjednosti saobraćaja svih korisnika, tako da putevi naselja budu jednako bezbjedni za sve učesnike u saobraćaju Pri tome rizik smrtnog stradanja u saobraćaju na putevima naselja je indirektno eksponencijalno povezan sa obimom sadržaja inkluzivnog menadžmenta bezbjednosti infrastrukture puteva u naselju.

Ključne riječi: inkluzivni menadžment, bezbjednost infrastrukture puteva u naselju, zaštita, ranjivi učesnici u saobraćaju 